\title{
Sensitivity to grid resolution in the ability of a chemical transport model to simulate observed oxidant chemistry under high-isoprene conditions
}

\author{
Karen Yu ${ }^{1}$, Daniel J. Jacob ${ }^{1,2}$, Jenny A. Fisher ${ }^{3,4}$, Patrick S. Kim ${ }^{2}$, Eloise A. Marais ${ }^{1}$, Christopher C. Miller ${ }^{1}$, \\ Katherine R. Travis ${ }^{1}$, Lei Zhu ${ }^{1}$, Robert M. Yantosca ${ }^{1}$, Melissa P. Sulprizio ${ }^{1}$, Ron C. Cohen ${ }^{5}$, Jack E. Dibb ${ }^{6}$, \\ Alan Fried ${ }^{7}$, Tomas Mikoviny ${ }^{8}$, Thomas B. Ryerson ${ }^{9}$, Paul O. Wennberg ${ }^{10,11}$, and Armin Wisthaler ${ }^{8,12}$ \\ ${ }^{1}$ School of Engineering and Applied Sciences, Harvard University, Cambridge, MA, USA \\ ${ }^{2}$ Department of Earth and Planetary Sciences, Harvard University, Cambridge, MA, USA \\ ${ }^{3}$ Centre for Atmospheric Chemistry, School of Chemistry, University of Wollongong, Wollongong, NSW, Australia \\ ${ }^{4}$ School of Earth and Environmental Sciences, University of Wollongong, Wollongong, NSW, Australia \\ ${ }^{5}$ Department of Chemistry, University of California, Berkeley, CA, USA \\ ${ }^{6}$ Earth System Research Center, University of New Hampshire, Durham, NH, USA \\ ${ }^{7}$ Institute for Arctic and Alpine Research, University of Colorado, Boulder, CO, USA \\ ${ }^{8}$ Department of Chemistry, University of Oslo, Oslo, Norway \\ ${ }^{9}$ Earth System Research Laboratory, National Oceanic and Atmospheric Administration, Boulder, CO, USA \\ ${ }^{10}$ Division of Geological and Planetary Sciences, California Institute of Technology, Pasadena, CA, USA \\ ${ }^{11}$ Division of Engineering and Applied Sciences, California Institute of Technology, Pasadena, CA, USA \\ ${ }^{12}$ Institute for Ion Physics and Applied Physics, University of Innsbruck, Innsbruck, Austria
}

Correspondence to: Karen Yu (kyu@ seas.harvard.edu)

Received: 5 December 2015 - Published in Atmos. Chem. Phys. Discuss.: 18 January 2016

Revised: 26 March 2016 - Accepted: 29 March 2016 - Published: 7 April 2016

\begin{abstract}
Formation of ozone and organic aerosol in continental atmospheres depends on whether isoprene emitted by vegetation is oxidized by the high- $\mathrm{NO}_{x}$ pathway (where peroxy radicals react with $\mathrm{NO}$ ) or by low- $\mathrm{NO}_{x}$ pathways (where peroxy radicals react by alternate channels, mostly with $\mathrm{HO}_{2}$ ). We used mixed layer observations from the SEAC ${ }^{4} \mathrm{RS}$ aircraft campaign over the Southeast US to test the ability of the GEOS-Chem chemical transport model at different grid resolutions $\left(0.25^{\circ} \times 0.3125^{\circ}, 2^{\circ} \times 2.5^{\circ}, 4^{\circ} \times 5^{\circ}\right)$ to simulate this chemistry under high-isoprene, variable- $\mathrm{NO}_{x}$ conditions. Observations of isoprene and $\mathrm{NO}_{x}$ over the Southeast US show a negative correlation, reflecting the spatial segregation of emissions; this negative correlation is captured in the model at $0.25^{\circ} \times 0.3125^{\circ}$ resolution but not at coarser resolutions. As a result, less isoprene oxidation takes place by the high- $\mathrm{NO}_{x}$ pathway in the model at $0.25^{\circ} \times 0.3125^{\circ}$ resolution $(54 \%)$ than at coarser resolution $(59 \%)$. The cumulative probability distribution functions (CDFs) of $\mathrm{NO}_{x}$,
\end{abstract}

isoprene, and ozone concentrations show little difference across model resolutions and good agreement with observations, while formaldehyde is overestimated at coarse resolution because excessive isoprene oxidation takes place by the high- $\mathrm{NO}_{x}$ pathway with high formaldehyde yield. The good agreement of simulated and observed concentration variances implies that smaller-scale non-linearities (urban and power plant plumes) are not important on the regional scale. Correlations of simulated vs. observed concentrations do not improve with grid resolution because finer modes of variability are intrinsically more difficult to capture. Higher model resolution leads to decreased conversion of $\mathrm{NO}_{x}$ to organic nitrates and increased conversion to nitric acid, with total reactive nitrogen oxides $\left(\mathrm{NO}_{y}\right)$ changing little across model resolutions. Model concentrations in the lower free troposphere are also insensitive to grid resolution. The overall low sensitivity of modeled concentrations to grid resolution implies that coarse resolution is adequate when model- 
ing continental boundary layer chemistry for global applications.

\section{Introduction}

Global simulations of tropospheric chemistry present a major computational challenge. Chemical mechanisms typically include over 100 coupled species, with lifetimes ranging from less than a second to more than a year, interacting with transport on all scales from concentrated emission plumes to the remote troposphere. This complexity has hindered the inclusion of detailed tropospheric chemistry in climate models (National Research Council, 2012) and generated considerable discussion over the importance of spatial resolution. Global models typically have a horizontal resolution of $\sim 100 \mathrm{~km}$, which does not properly resolve chemical gradients and may lead to large errors from non-linear chemistry and coupling to transport. On the other hand, increasing resolution is computationally expensive and may require trade-offs in other aspects of the model. Here we apply a global chemical transport model (GEOS-Chem CTM) to simulate extensive boundary layer observations of ozone and related species over the Southeast US from the SEAC ${ }^{4}$ RS aircraft campaign (Toon et al., 2016; SEAC4RS Science Team, 2016). We explore how varying grid resolution from $4^{\circ} \times 5^{\circ}$ $\left(\approx 400 \times 400 \mathrm{~km}^{2}\right)$ to $0.25^{\circ} \times 0.3125^{\circ}\left(\approx 28 \times 28 \mathrm{~km}^{2}\right)$ affects model results and the ability to simulate observations.

Ozone $\left(\mathrm{O}_{3}\right)$ production is central to driving the complexity of chemical mechanisms. It is controlled by reaction chains involving hydrogen oxide radicals $\left(\mathrm{HO}_{x} \equiv \mathrm{OH}+\right.$ peroxy radicals), nitrogen oxide radicals $\left(\mathrm{NO}_{x} \equiv \mathrm{NO}+\mathrm{NO}_{2}\right)$, halogen radicals, volatile organic compounds (VOCs), and a large ensemble of reservoir and product species. NO and VOCs are emitted by a wide range of sources, both natural and anthropogenic. $\mathrm{NO}_{x}$ typically has a lifetime of hours while VOCs have lifetimes ranging from minutes to years (Atkinson and Arey, 2003). Their interactions result in a diversity of chemical regimes.

A number of studies have examined the effect of model resolution on ozone production in urban regions (Sillman et al., 1990; Jang et al., 1995; Gillani and Pleim, 1996; Kumar and Russell, 1996; Chock et al., 2002; Esler et al., 2004). A typical result is that dilution from grid averaging causes positive bias in the ozone production efficiency (OPE) per unit $\mathrm{NO}_{x}$ emitted (Liu et al., 1987). Liang and Jacobson (2000) showed that premature mixing of urban and background air masses can lead to either overestimates or underestimates of OPE. Model simulations of ship plumes indicate particularly large ozone overestimates when mixing $\mathrm{NO}_{x}$ from the plumes into otherwise clean grid cells (Davis et al., 2001; Vinken et al., 2011). On a global scale, Wild and Prather (2006) found from an asymptotic error convergence method that grid averaging in a $2.8^{\circ} \times 2.8^{\circ}$ model caused a $+4 \%$ bias in the global tropospheric ozone burden, with larger errors on regional scales. Ito et al. (2009) compared global models of varying resolutions and concluded that artificial mixing of biogenic VOC emissions into coarse grid cells drives excessive conversion of $\mathrm{NO}_{x}$ to organic nitrate reservoirs, leading to release of $\mathrm{NO}_{x}$ downwind under higher OPE conditions and thereby causing excessive ozone production.

The interaction between $\mathrm{NO}_{2}$ and $\mathrm{OH}$, the dominant $\mathrm{NO}_{2}$ oxidant, can also lead to biases in model estimates of $\mathrm{NO}_{2}$ tropospheric columns for comparison to satellite observations. Valin et al. (2011) found that large point sources of $\mathrm{NO}_{x}$ titrate $\mathrm{OH}$, producing long-lived $\mathrm{NO}_{x}$ plumes. Dilution of these plumes into coarse resolution grid cells shortens the $\mathrm{NO}_{x}$ lifetime, leading to underestimation of $\mathrm{NO}_{2}$ columns. Yamaji et al. (2014) found that coarse resolution CTMs tend to underestimate retrievals of $\mathrm{NO}_{2}$ columns over industrial regions.

The SEAC ${ }^{4}$ RS observations provide an opportunity to investigate the effect of chemical non-linearity in an environment with very high biogenic VOC emissions (mainly isoprene) and variable levels of $\mathrm{NO}_{x}$ (mostly from combustion). The interactions between these species define oxidant (ozone and $\mathrm{OH}$ ) chemistry. Isoprene is oxidized by the $\mathrm{OH}$ radical on a timescale of an hour to produce isoprene peroxy radicals $\left(\mathrm{ISOPO}_{2}\right)$. These $\mathrm{ISOPO}_{2}$ radicals may either react with $\mathrm{NO}$ to produce ozone (high- $\mathrm{NO}_{x}$ pathway) or react by other channels (low- $\mathrm{NO}_{x}$ pathways). Grid averaging may affect the ability to resolve the different pathways with implications for ozone, oxidant chemistry in general, and the formation of secondary organic aerosol (SOA) (Marais et al., 2016). It may also affect the ability to simulate variability in chemical concentrations, especially events at the high tails of the probability distributions. Higher resolution enables better simulation of chemical gradients, with some benefit for capturing extreme values (Zhang et al., 2011). However, higher model resolution does not always improve the correlations with observed concentrations (Kiley et al., 2003; Mathur et al., 2005; Arunachalam et al., 2006; Valari and Menut, 2008) because finer modes of variability are harder to capture than coarser modes (Fiore et al., 2003).

\section{Methods}

The GEOS-Chem simulation for the SEAC ${ }^{4} \mathrm{RS}$ period (August-September 2013) uses GEOS-5 assimilated meteorological data produced by the NASA Global Modeling and Assimilation Office (GMAO) at $0.25^{\circ} \times 0.3125^{\circ}$ horizontal resolution with 72 vertical layers and $3 \mathrm{~h}$ temporal resolution ( $1 \mathrm{~h}$ for surface quantities and mixing depths). Here we use that native resolution as reference for comparison to the $2^{\circ} \times 2.5^{\circ}$ and $4^{\circ} \times 5^{\circ}$ resolutions routinely adopted by the GEOS-Chem user community (http://geos-chem.org) for global applications. Companion GEOS-Chem studies ap- 


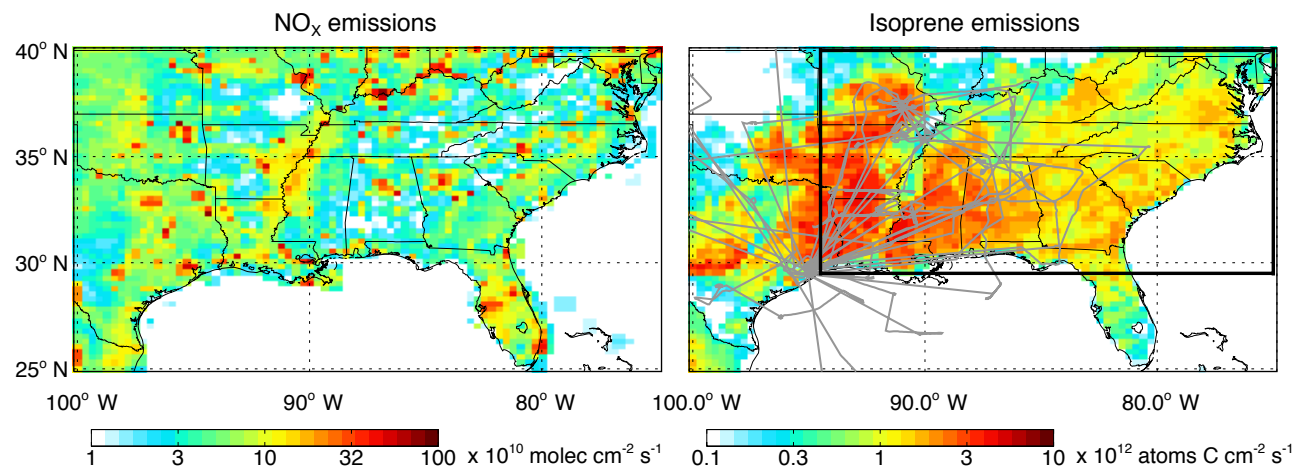

Figure 1. GEOS-Chem surface emissions of $\mathrm{NO}_{x}$ and isoprene in August 2013 at $0.25^{\circ} \times 0.3125^{\circ}$ resolution. See text for emission inventory references. $\mathrm{NO}_{x}$ emissions shown here include contributions from combustion and soils but not lightning. Gray lines on isoprene panel indicate flight tracks of the DC- 8 during the SEAC ${ }^{4} \mathrm{RS}$ campaign. The black line delineates the Southeast US as used for regional budget analyses in the text.

ply the model with $0.25^{\circ} \times 0.3125^{\circ}$ resolution to interpret $\mathrm{SEAC}^{4} \mathrm{RS}$ observations of organic nitrates (Fisher et al., 2016), ozone (Travis et al., 2016), aerosols (Kim et al., 2015), and formaldehyde (Zhu et al., 2016). Marais et al. (2016) uses $2^{\circ} \times 2.5^{\circ}$ resolution to simulate isoprene secondary organic aerosol in SEAC ${ }^{4} \mathrm{RS}$. These references present relevant model descriptions and evaluation.

The $0.25^{\circ} \times 0.3125^{\circ}$ simulation extends over a continental-scale North America window $\left(130-60^{\circ} \mathrm{W}\right.$, $\left.9.75-60^{\circ} \mathrm{N}\right)$. Initial and dynamic boundary conditions are from a global simulation with $4^{\circ} \times 5^{\circ}$ resolution serving as outer nest (Chen et al., 2009). The chemical time step is $10 \mathrm{~min}$ at $0.25^{\circ} \times 0.3125^{\circ}$ resolution, $30 \mathrm{~min}$ at $2^{\circ} \times 2.5^{\circ}$, and $60 \mathrm{~min}$ at $4^{\circ} \times 5^{\circ}$. The transport time step is half the chemical time step.

The SEAC ${ }^{4} \mathrm{RS}$ simulation is based on GEOS-Chem version 9-02 (http://wiki.seas.harvard.edu/geos-chem/index. php/GEOS-Chem_v9-02) including a detailed mechanism for $\mathrm{HO}_{x}-\mathrm{NO}_{x}-\mathrm{VOC}-\mathrm{O}_{3}$-bromine-aerosol tropospheric chemistry with 196 chemical species (Parrella et al., 2012; Mao et al., 2013). Isoprene chemistry is updated as described by Travis et al. (2016). US anthropogenic emissions are from the 2011 National Emissions Inventory (NEI), with national scaling for 2013 and $60 \%$ downward correction for $\mathrm{NO}_{x}$ as described in Travis et al. (2016). Biogenic emissions are from the Model of Emissions of Gases and Aerosols from Nature (MEGANv2.1) (Guenther et al., 2012) with $15 \%$ downward correction for isoprene emission (Zhu et al., 2016). Lightning $\mathrm{NO}_{x}$ emissions are constrained by satellite observations as described in Murray et al. (2012). Soil $\mathrm{NO}_{x}$ emissions, including fertilizer, are from Hudman et al. (2012) with Jacob and Wofsy (1990) canopy reduction factors.

Figure 1 shows the emissions of $\mathrm{NO}_{x}$ and isoprene over the Southeast US domain at $0.25^{\circ} \times 0.3125^{\circ}$ resolution. Isoprene emission is mainly from forests and $\mathrm{NO}_{x}$ emission is mostly from mobile sources and power plants (Travis et al., 2016). The resulting spatial segregation between isoprene and $\mathrm{NO}_{x}$ emissions has important implications for whether isoprene oxidation takes place by high- $\mathrm{NO}_{x}$ or low- $\mathrm{NO}_{x}$ pathways. We ensure that emission totals are the same at all model resolutions so that they are not a factor of differences in results. This required minor scaling of biogenic VOC emissions that depend on environmental variables.

Comparisons between model and aircraft observations use model output sampled along the DC-8 flight tracks (Fig. 1), and observations from a $60 \mathrm{~s}$ merged data set. For computing aggregate statistics, such as probability distributions, we use observations directly from the $60 \mathrm{~s}$ data set. For computing correlations between model and observations, we average data over model grid cells along individual flight tracks. We focus on daytime continental data over the Southeast US domain $\left(94.5-75^{\circ} \mathrm{W}, 29.5-40^{\circ} \mathrm{N}\right.$, box in Fig. 1) and within the mixed layer as determined from lidar measurements aboard the aircraft (Hair et al., 2008). Typical mixed layer heights (10th and 90th percentiles) during the campaign ranged from 600 to $2200 \mathrm{~m}$, with a mean value of $1500 \mathrm{~m}$. The aircraft occasionally targeted fire plumes and we remove those as diagnosed by measured acetonitrile concentrations exceeding 225 ppt. Our analysis domain also excludes the Houston plume, targeted on two SEAC ${ }^{4} \mathrm{RS}$ flights (16 and 18 September) and for which our model would not be expected to give a representative simulation.

\section{Segregation of high-NO $x$ and low-NO $x$ isoprene oxidation pathways}

Oxidant chemistry and SOA formation over the Southeast US in summer is largely determined by whether isoprene oxidation follows the high- $\mathrm{NO}_{x}$ or low- $\mathrm{NO}_{x}$ pathways (Marais et al., 2016; Travis et al., 2016). Travis et al. (2016) diagnosed the prevalence of different isoprene oxidation pathways in the GEOS-Chem $\left(0.25^{\circ} \times 0.3125^{\circ}\right)$ simulation of the Southeast US during SEAC ${ }^{4} \mathrm{RS}$ on the basis of the fate of the first-generation $\mathrm{ISOPO}_{2}$ radicals. They found on average 


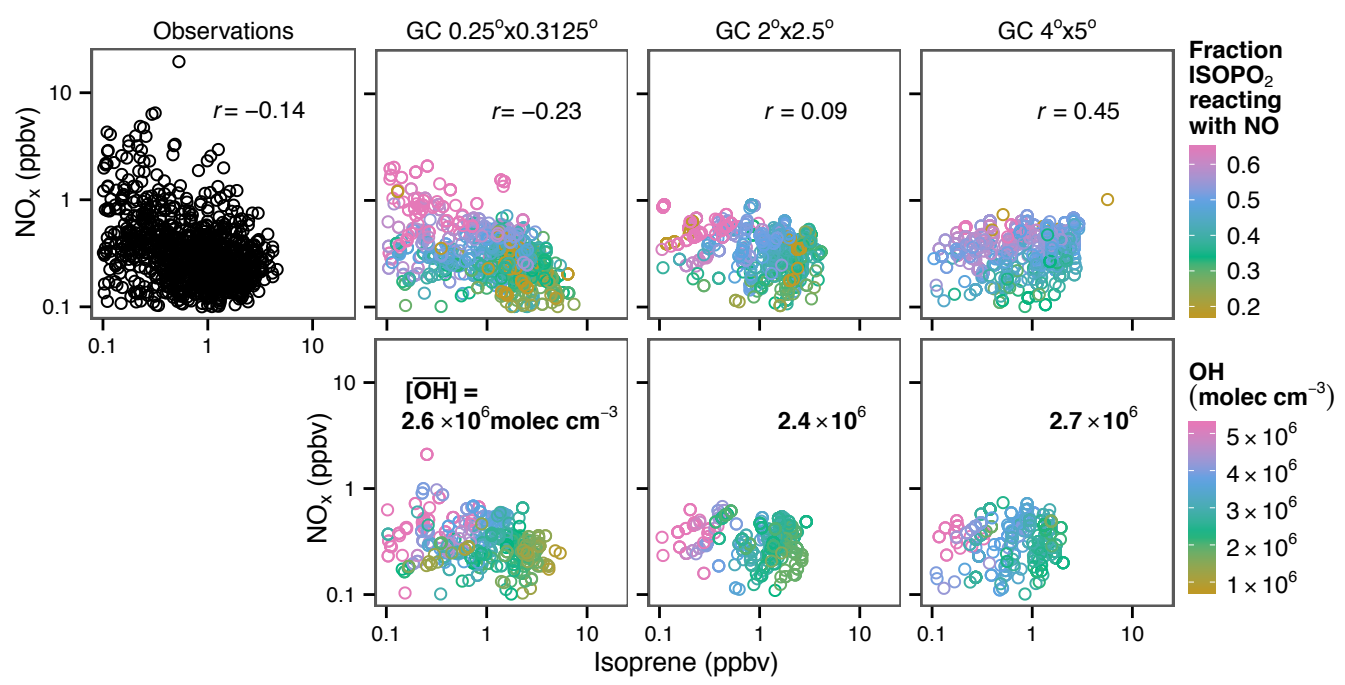

Figure 2. Relationship between $\mathrm{NO}_{x}$ and isoprene concentrations in the mixed layer in $\mathrm{SEAC}^{4} \mathrm{RS}$. Observations (60-s average) are compared to the GEOS-Chem (GC) simulations at different resolutions sampled along the flight tracks over the Southeast US domain of Fig. 1. Pearson's correlation coefficients $(r)$ are inset. The top model panels are colored by the fraction of the first-generation isoprene peroxy radical (ISOPO 2 ) reacting with $\mathrm{NO}$; a fraction less than 0.5 indicates that low- $\mathrm{NO}_{x}$ pathways dominate for isoprene oxidation. The bottom model panels are colored by the $\mathrm{OH}$ concentration, restricted to midday points (10:30-14:30 local time). Regional mean values computed along the flight tracks (primarily daytime) are given inset.

that $56 \%$ of $\mathrm{ISOPO}_{2}$ radicals reacted with $\mathrm{NO}$ (high- $\mathrm{NO}_{x}$ pathway). The low- $\mathrm{NO}_{x}$ pathways mostly involved reaction of $\mathrm{ISOPO}_{2}$ with $\mathrm{HO}_{2}(25 \%), \mathrm{ISOPO}_{2}$ isomerization (15\%), and reactions with other organic peroxy radicals $(4 \%)$. The transition from high- to low- $\mathrm{NO}_{x}$ pathways occurred at an $\mathrm{NO}$ concentration of about $60 \mathrm{ppt}$, corresponding to a $\mathrm{NO}_{x}$ concentration of about 300 ppt.

The effect of the geographical segregation between $\mathrm{NO}_{x}$ and isoprene emissions is illustrated in Fig. 2, which shows the relationship between $\mathrm{NO}_{x}$ and isoprene concentrations along the flight tracks. $\mathrm{NO}_{x}$ was measured by chemiluminescence (Ryerson et al., 2000) and isoprene by proton-transferreaction mass spectrometry (PTR-MS) (Hansel et al., 1999). The observations show a negative correlation that is captured in the simulation at $0.25^{\circ} \times 0.3125^{\circ}$ resolution but not at coarser resolutions. The $4^{\circ} \times 5^{\circ}$ simulation actually shows positive correlations, likely reflecting a common sensitivity to stagnation and resulting high temperatures. We find in the model that $\mathrm{NO}_{x}$ concentrations are strongly correlated with surface air temperature on the $4^{\circ} \times 5^{\circ}(r=0.66)$ but not on the $0.25^{\circ} \times 0.3125^{\circ}$ scale $(r=0.17)$.

For the $\mathrm{SEAC}^{4} \mathrm{RS}$ data set sampled along the flight tracks, the $0.25^{\circ} \times 0.3125^{\circ}$ simulation finds that $42 \%$ of the $\mathrm{ISOPO}_{2}$ radicals react with NO. That fraction increases to $44 \%$ for the $2^{\circ} \times 2.5^{\circ}$ simulation and $49 \%$ for the $4^{\circ} \times 5^{\circ}$ simulation. Over the whole Southeast US domain (box in Fig. 1), the fraction of $\mathrm{ISOPO}_{2}$ radicals reacting by the high$\mathrm{NO}_{x}$ pathway is $54 \%$ at $0.25^{\circ} \times 0.3125^{\circ}$ resolution and $59 \%$ at the $2^{\circ} \times 2.5^{\circ}$ and $4^{\circ} \times 5^{\circ}$ resolutions. Our values differ slightly from Travis et al. (2016) because we did not exclude

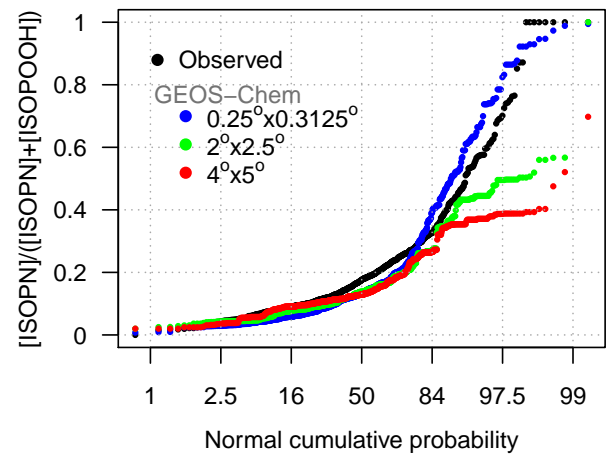

Figure 3. Cumulative probability distribution functions (CDFs) of the $\frac{[\mathrm{ISOPN}]}{[\mathrm{ISOPN}]+[\mathrm{ISOPOOH}]}$ ratio measuring the relative importance of the high-NO $\mathrm{N}_{x}$ pathway vs. low- $\mathrm{NO}_{x}$ pathways for isoprene oxidation. High values of the ratio indicate a dominant high- $\mathrm{NO}_{x}$ pathway. Mixed layer observations from the SEAC ${ }^{4} \mathrm{RS}$ aircraft over the Southeast US are compared to GEOS-Chem output along the flight tracks at different resolutions. The $x$ axis is a normal probability scale such that a normal distribution would plot on a straight line.

ocean grid cells in the domain in order to keep comparisons between different resolutions consistent.

We see that the branching ratio between high- $\mathrm{NO}_{x}$ and low- $\mathrm{NO}_{x}$ pathways for isoprene oxidation is much less sensitive to model resolution than would be expected from the segregation of isoprene and $\mathrm{NO}_{x}$ emissions. This is due to $\mathrm{OH}$ depletion under low- $\mathrm{NO}_{x}$ conditions prolonging the lifetime of isoprene and its oxidation products, allowing them to travel to higher- $\mathrm{NO}_{x}$ environments before being oxidized. 


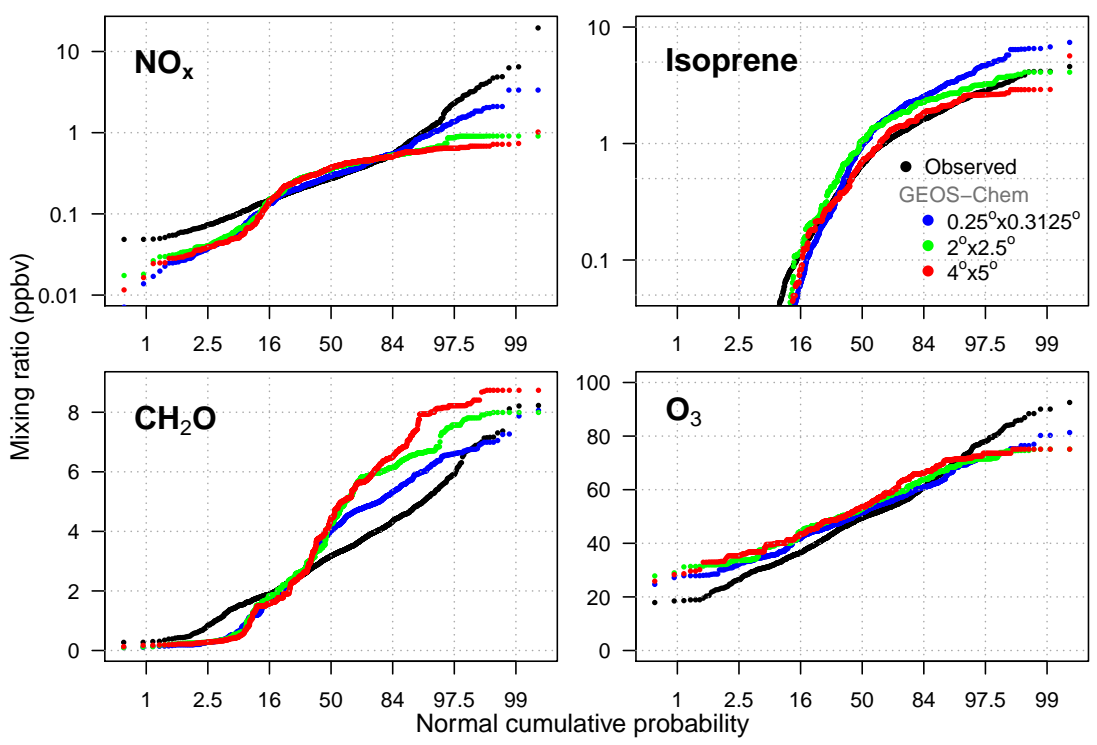

Figure 4. Cumulative probability distribution functions $(\mathrm{CDFs})$ of $\mathrm{NO}_{x}$, isoprene, formaldehyde $\left(\mathrm{CH}_{2} \mathrm{O}\right)$, and ozone $\left(\mathrm{O}_{3}\right)$ concentrations in the Southeast US mixed layer during the SEAC ${ }^{4} \mathrm{RS}$ aircraft campaign. Observations are compared to GEOS-Chem model values at different resolutions $\left(0.25^{\circ} \times 0.3125^{\circ}, 2^{\circ} \times 2.5^{\circ}, 4^{\circ} \times 5^{\circ}\right)$ sampled along the flight tracks over the Southeast US domain of Fig. 1 . The $x$ axis is a normal probability scale such that a normal distribution (formaldehyde, ozone) or lognormal distribution $\left(\mathrm{NO}_{x}\right.$, isoprene) would plot on a straight line.

The bottom panels of Fig. 2 show the dependence of midday, mixed layer model $\mathrm{OH}$ concentrations at different resolutions on $\mathrm{NO}_{x}$ and isoprene concentrations along the SEAC ${ }^{4} \mathrm{RS}$ flight tracks. The depletion of $\mathrm{OH}$ under low- $\mathrm{NO}_{x}$, highisoprene conditions is apparent and is better represented at the finer resolution: the implication is that isoprene is more likely to be oxidized under higher $\mathrm{NO}_{x}$ conditions than at its point of emission. Although regional mean $\mathrm{OH}$ concentration (computed along flight tracks) varies with grid resolution, the change is not monotononic as shown inset in the figure.

The SEAC ${ }^{4} \mathrm{RS}$ aircraft payload included measurements of first-generation isoprene nitrates (ISOPN), a product of the high- $\mathrm{NO}_{x}$ pathway, and ISOPOOH, the principal product of the $\mathrm{HO}_{2}$ pathway (Crounse et al., 2006). Figure 3 shows a cumulative probability distribution function (CDF) plot of the $[\mathrm{ISOPN}] /([\mathrm{ISOPOOH}]+[\mathrm{ISOPN}])$ ratio in the Southeast US mixed layer, providing a diagnostic of whether isoprene oxidation proceeds by the high- $\mathrm{NO}_{x}$ pathway (high ratio) or the low-NO $\mathrm{N}_{x}$ pathways (low ratio). We see that the $0.25^{\circ} \times 0.3125^{\circ}$ simulation is more consistent with observations than the $2^{\circ} \times 2.5^{\circ}$ and $4^{\circ} \times 5^{\circ}$ simulations, although the difference is mainly for the high tail of the distribution.

\section{Chemical variability and bias}

Figure 4 shows the simulated and observed CDFs of $\mathrm{NO}_{x}$, isoprene, formaldehyde, and ozone concentrations sampled along the flight tracks in the Southeast US mixed layer. Formaldehyde was measured by the Compact Atmospheric
Multispecies Spectrometer (CAMS) (Richter et al., 2015) and ozone by chemiluminescence (Ryerson et al., 2000). $\mathrm{NO}_{x}$ and isoprene are primary (directly emitted) and have mean lifetimes against chemical loss of a few hours and less than an hour, respectively. The $\mathrm{NO}_{x}$ distribution is approximately lognormal while isoprene is better described by a Weibull distribution. Formaldehyde and ozone are secondary (chemically produced) and their distributions are more normal. Most of the formaldehyde in SEAC ${ }^{4} \mathrm{RS}$ originated from isoprene oxidation (Zhu et al., 2016).

We find that, with the exception of formaldehyde, differences between the different model resolutions are mainly at the high tails of the distributions. In the case of $\mathrm{NO}_{x}$, the highest resolution model better captures the high tail in the observations due to urban plumes. In the case of isoprene the highest resolution model over-predicts the high tail in the observations, which could reflect errors in the fine structure of MEGAN emissions or excessive local depletion of $\mathrm{OH}$ (the main isoprene sink) as a result of high isoprene. In the case of ozone, the highest resolution model only marginally improves the simulation of the high tail in the observations (industrial plumes downwind of Port Arthur, Texas), for which even $0.25^{\circ} \times 0.3125^{\circ}$ may not provide adequate resolution. In the case of formaldehyde, the highest resolution model actually produces weaker maxima that are more consistent with observations. Production of formaldehyde from isoprene oxidation has a higher yield in the high- $\mathrm{NO}_{x}$ pathway than the low-NO $\mathrm{N}_{x}$ pathways (Marais et al., 2012). High isoprene is associated with low $\mathrm{NO}_{x}$ in the observations (Fig. 2) and therefore with a low formaldehyde yield but this is captured only 


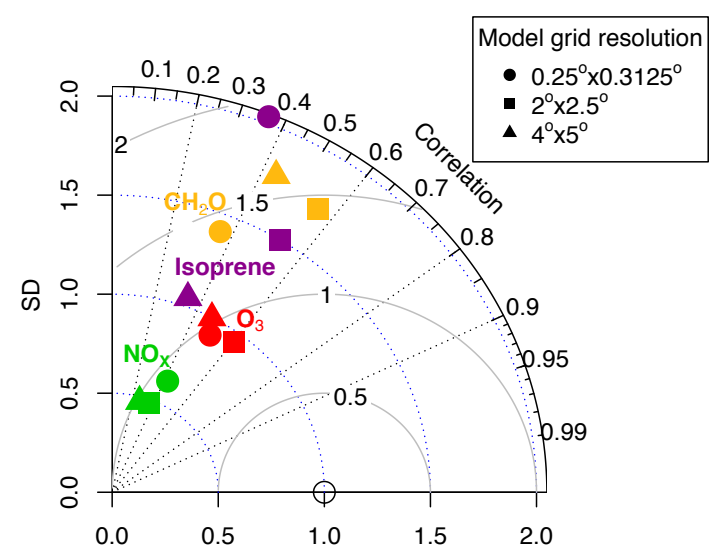

Figure 5. Taylor Diagram for $\mathrm{NO}_{x}$, isoprene, formaldehyde, and ozone concentration statistics sampled in the Southeast US mixed layer along SEAC ${ }^{4}$ RS flight tracks (Figs. 1 and 4). GEOS-Chem model results at different grid resolutions are compared to observations at the corresponding resolutions. Standard deviation is plotted along the radial coordinate, while the angular coordinate denotes the Pearson's correlation coefficient between model and observations. Model standard deviation is normalized to the observations, so that a value above 1 indicates greater variance than observed. The open circle located at $(1,1)$ represents the observations. The grey arcs represent the root-mean-squared error between model and observations after the mean bias has been removed.

at the highest model resolution. This result has important implications for the use of formaldehyde-isoprene model relationships to infer isoprene emissions from satellite measurements of formaldehyde columns (Palmer et al., 2003). Relationships derived from coarse-resolution models overestimate the yield of formaldehyde from isoprene emission.

Except for formaldehyde, the bulk of the distributions shows very little difference between model results at different resolutions, despite $\mathrm{NO}_{x}$ levels spanning 4 orders of magnitude. This suggests that the coarser resolutions are adequate for simulating regional averages. Non-linear effects have been reported in previous model studies at the kilometer scale of urban areas (Kumar and Russell, 1996; Chock et al., 2002; Shrestha et al., 2009; Tie et al., 2010) or pollution plumes (Henderson et al., 2010; Valin et al., 2011), and these small-scale effects are not resolved here even at $0.25^{\circ} \times 0.3125^{\circ}$ resolution. Nevertheless, the general ability of the GEOS-Chem simulation to capture the variance in the SEAC ${ }^{4} \mathrm{RS}$ observations implies that small-scale effects are not of major importance at least for the Southeast US.

Figure 5 presents a Taylor Diagram of modeled $\mathrm{NO}_{x}$, isoprene, formaldehyde, and ozone concentration statistics compared to observations averaged to the corresponding model grid and timestep. The Taylor Diagram is a concise graphical summary of how well two patterns match each other in terms of their correlation, root mean squared difference, and variances (Taylor, 2001). Comparison of variances for different resolutions is consistent with the previously discussed

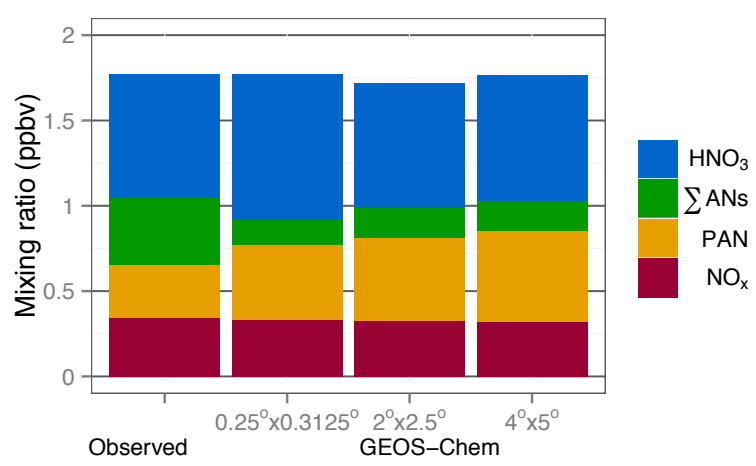

Figure 6. Mean concentrations of reactive nitrogen oxides $\left(\mathrm{NO}_{y}\right)$ species over the Southeast US during SEAC ${ }^{4}$ RS. Aircraft observations in the mixed layer over the Southeast US domain of Fig. 1 are compared to GEOS-Chem model values at different resolutions. $\Sigma$ ANs refers to the sum of alkyl and multifunctional nitrates and PAN to peroxyacetylnitrate. Observations are from T. Ryerson for $\mathrm{NO}_{x}$, R. Cohen for $\Sigma$ ANs, G. Huey for PAN, and J. Dibb for nitric acid $\left(\mathrm{HNO}_{3}\right)$ (Toon et al., 2016).

information from Fig. 4. Correlations with observations improve when resolution is increased from $4^{\circ} \times 5^{\circ}$ to $2^{\circ} \times 2.5^{\circ}$, but then generally degrade at $0.25^{\circ} \times 0.3125^{\circ}$ (except for $\mathrm{NO}_{x}$ ). This is because finer-scale features are more difficult to model (Kiley et al., 2003; Mathur et al., 2005; Arunachalam et al., 2006; Valari and Menut, 2008). A higher resolution model will be penalized for placing these features in the wrong place or time, while a coarse resolution model does not attempt to resolve them.

\section{Implications for global models}

From a global modeling perspective, the ability to simulate local extrema in a chemical source region is generally not critical and the focus instead is on simulation of regional means and export to the global atmosphere. From that standpoint, the general insensitivity of concentrations to model resolution over the bulk of the distributions suggests that coarse resolution is adequate for global modeling purposes. We confirm this result by examination of the regional budgets of total reactive nitrogen oxides $\left(\mathrm{NO}_{y} \equiv \mathrm{NO}_{x}+\right.$ oxidation products) and ozone over the Southeast US at different model resolutions.

Figure 6 shows mean simulated and observed daytime concentrations of $\mathrm{NO}_{y}$ species in the Southeast US mixed layer during SEAC ${ }^{4} \mathrm{RS}$. Total $\mathrm{NO}_{y}$ in the model is within $10 \%$ of observations, at all resolutions, but there is somewhat more difference in the speciation of $\mathrm{NO}_{x}$ oxidation products. The $0.25^{\circ} \times 0.3125^{\circ}$ simulation has lower peroxyacetylnitrate (PAN) than the coarser resolutions, in better agreement with observations, due to less artificial mixing of $\mathrm{NO}_{x}$ and isoprene emissions as previously pointed out by Ito et al. (2009). All model resolutions show similar low bias rel- 


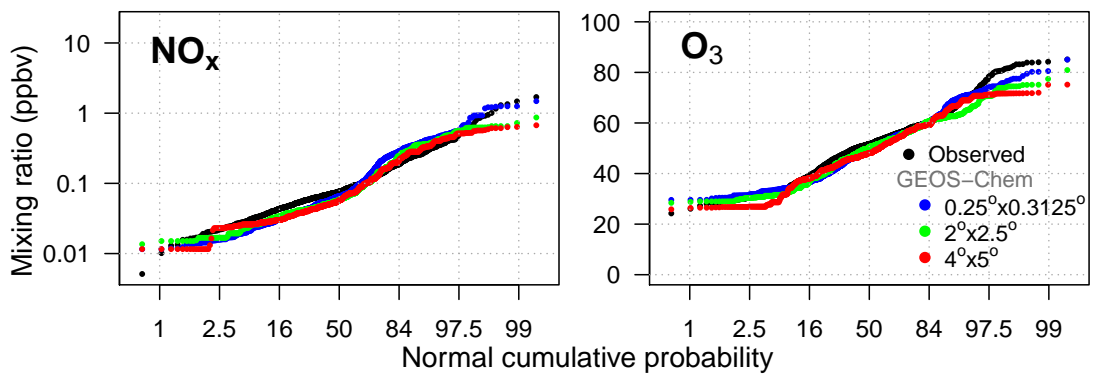

Figure 7. Cumulative probability distribution functions (CDFs) of $\mathrm{NO}_{x}$ and ozone $\left(\mathrm{O}_{3}\right)$ concentrations in the lower free troposphere over the Southeast US (from mixed layer top to $4 \mathrm{~km}$ altitude) during the SEAC ${ }^{4} \mathrm{RS}$ aircraft campaign. Observations are compared to GEOSChem model values at different resolutions sampled along the flight tracks over the Southeast US domain of Fig. 1. The $x$ axis is a normal probability scale such that a normal distribution (ozone) or lognormal distribution $\left(\mathrm{NO}_{x}\right)$ would plot as a straight line.

ative to observed total alkyl nitrates ( $\Sigma$ ANs). This low bias is discussed in Fisher et al. (2016). The model has larger nitric acid concentrations at higher resolution because it resolves better the positive correlation between $\mathrm{NO}_{x}$ and $\mathrm{OH}$ concentrations (Fig. 2). We find that the regional mean $\mathrm{NO}_{x}$ lifetime with respect to conversion to nitric acid is 0.66 days for the $4^{\circ} \times 5^{\circ}$ model, 0.62 days for the $2^{\circ} \times 2.5^{\circ}$ model, and 0.51 days for the $0.25^{\circ} \times 0.3125^{\circ}$ model. Although simulated regional mean $\mathrm{OH}$ concentrations do not change monotonically with resolution, the higher resolution model captures better the association of elevated $\mathrm{OH}$ with $\mathrm{NO}_{x}$.

From a global model perspective, chemical venting from continental source regions such as the Southeast US is of paramount importance. Figure 7 shows CDF plots for ozone and $\mathrm{NO}_{x}$ in the lower free troposphere (from mixed layer top to $4 \mathrm{~km}$ altitude). Model results are insensitive to resolution, with differences even smaller than in the mixed layer. As in the mixed layer, all model resolutions simulate the median of the distributions well, and differences across model resolution occur mainly at the tails of the distributions. Overall, we find that grid resolution has little effect on the export of ozone and its precursors out of the mixed layer.

\section{Conclusions}

Production of ozone and organic aerosol in continental atmospheres is highly sensitive to whether isoprene emitted by vegetation is oxidized by the high- $\mathrm{NO}_{x}$ pathway (where peroxy radicals react with $\mathrm{NO}$ ) or by the low- $\mathrm{NO}_{x}$ pathways (where peroxy radicals react mostly with $\mathrm{HO}_{2}$ ). This distinction between pathways is becoming increasingly relevant in the US as anthropogenic $\mathrm{NO}_{x}$ emissions decrease. In this work, we used SEAC ${ }^{4} \mathrm{RS}$ aircraft observations in the mixed layer over the Southeast US to test the ability of the GEOSChem chemical transport model (CTM) at different horizontal resolutions $\left(0.25^{\circ} \times 0.3125^{\circ}, 2^{\circ} \times 2.5^{\circ}, 4^{\circ} \times 5^{\circ}\right)$ to simulate the different pathways and the resulting variability in concentrations. $2^{\circ} \times 2.5^{\circ}$ and $4^{\circ} \times 5^{\circ}$ are the standard resolutions used in global GEOS-Chem simulations of tropospheric chemistry while the $0.25^{\circ} \times 0.3125^{\circ}$ continental-scale resolution is a new GEOS-Chem capability.

Emissions of $\mathrm{NO}_{x}$ and isoprene are spatially segregated $\left(\mathrm{NO}_{x}\right.$ in urban centers, isoprene in forests). SEAC ${ }^{4} \mathrm{RS}$ observations in the mixed layer show a negative correlation between isoprene and $\mathrm{NO}_{x}$ concentrations that is captured in the model at $0.25^{\circ} \times 0.3125^{\circ}$ resolution but not at coarser resolution. $54 \%$ of isoprene oxidation in the Southeast US takes place by the high- $\mathrm{NO}_{x}$ pathway in the $0.25^{\circ} \times 0.3125^{\circ}$ resolution model, as compared to $59 \%$ at the coarser resolutions. Observed ratios of isoprene nitrates (ISOPN) to isoprene hydroperoxides (ISOPOOH) show segregation between high- and low- $\mathrm{NO}_{x}$ pathways that is better captured at $0.25^{\circ} \times 0.3125^{\circ}$ than at coarser resolutions. The segregation between high- and low- $\mathrm{NO}_{x}$ pathways is less than would be expected from the segregation of $\mathrm{NO}_{x}$ and isoprene emissions because $\mathrm{OH}$ depletion in low- $\mathrm{NO}_{x}$ environments allows isoprene to travel to higher- $\mathrm{NO}_{x}$ environments to become oxidized.

We examined the ability of the model at different resolutions to simulate the observed probability distributions of $\mathrm{NO}_{x}$, isoprene, formaldehyde, and ozone concentrations across the Southeast US. Differences between model resolutions are mainly at the high tails of the distributions. There is remarkably little difference for the bulk of the distributions. An exception is formaldehyde, which is overestimated at coarser model resolution because more isoprene is oxidized by the high- $\mathrm{NO}_{x}$ pathway, with a higher formaldehyde yield. Inference of isoprene emissions from satellite observations of formaldehyde columns may be biased high if a coarse-resolution model is used for the formaldehydeisoprene relationship.

Spatial correlations between model and observations improve as resolution increases from $4^{\circ} \times 5^{\circ}$ to $2^{\circ} \times 2.5^{\circ}$ but then decreases as resolution increases further to $0.25^{\circ} \times 0.3125^{\circ}$. This shows that finer modes of variability are more difficult to capture in models of commensurate resolution, consistent with the results of previous studies such as Fiore et al. (2003) and Valari and Menut (2008). 
Increasing model resolution leads to faster conversion of $\mathrm{NO}_{x}$ to nitric acid, because $\mathrm{OH}$ correlates positively with $\mathrm{NO}_{x}$, while slowing down conversion to organic nitrates. However, the effect on the mean budget of reactive nitrogen oxides $\left(\mathrm{NO}_{y}\right)$ in the mixed layer is small. Furthermore, comparisons of $\mathrm{NO}_{x}$ and ozone concentrations in the lower free troposphere indicate no significant sensitivity to model resolution. Previous model studies have pointed out significant chemical non-linearities at the scale of urban and industrial plumes, smaller than the $0.25^{\circ} \times 0.3125^{\circ}$ resolution used here. However, the ability of GEOS-Chem to simulate the variability of concentrations observed in SEAC ${ }^{4} \mathrm{RS}$ implies that such small-scale effects are not important on the regional scale.

The overall relative insensitivity of oxidant chemistry to model resolution in the challenging environment of the Southeast US suggests that mean statistics of regional boundary layer chemistry can be simulated adequately at coarse resolution (such as $2^{\circ} \times 2.5^{\circ}$ ) for global modeling purposes.

Acknowledgements. We are grateful to the entire NASA SEAC ${ }^{4} \mathrm{RS}$ team for their help in the field. This work was funded by the NASA Atmospheric Composition Modeling and Analysis Program and by the NASA Tropospheric Chemistry Program. Jenny A. Fisher acknowledges financial support from a University of Wollongong Vice Chancellor's Postdoctoral Fellowship. Isoprene measurements during SEAC ${ }^{4}$ RS were supported by the Austrian Federal Ministry for Transport, Innovation and Technology (bmvit) through the Austrian Space Applications Programme (ASAP) of the Austrian Research Promotion Agency (FFG). Armin Wisthaler and Tomas Mikoviny received support from the Visiting Scientist Program at the National Institute of Aerospace (NIA).

Edited by: M. C. Facchini

\section{References}

Arunachalam, S., Holland, A., Do, B., and Abraczinskas, M.: A quantitative assessment of the influence of grid resolution on predictions of future-year air quality in North Carolina, USA, Atmos. Environ., 40, 5010-5026, doi:10.1016/j.atmosenv.2006.01.024, 2006.

Atkinson, R. and Arey, J.: Atmospheric degradation of volatile organic compounds, Chem. Rev., 103, 4605-4638, doi:10.1021/cr0206420, 2003.

Chen, D., Wang, Y., McElroy, M. B., He, K., Yantosca, R. M., and Le Sager, P.: Regional CO pollution and export in China simulated by the high-resolution nested-grid GEOS-Chem model, Atmos. Chem. Phys., 9, 3825-3839, doi:10.5194/acp-9-3825-2009, 2009.

Chock, D. P., Winkler, S. L., and Sun, P.: Effect of grid resolution and subgrid assumptions on the model prediction of a reactive bouyant plume under convective conditions, Atmos. Environ., 36, 4649-4662, doi:10.1016/S1352-2310(02)00422-3, 2002.

Crounse, J. D., McKinney, K. A., Kwan, A. J., and Wennberg, P. O.: Measurement of Gas-Phase Hydroperoxides by Chemi- cal Ionization Mass Spectrometry, Anal. Chem., 78, 6726-6732, doi:10.1021/ac0604235, 2006.

Davis, D. D., Grodzinsky, G., Kasibhatla, P., Crawford, J., Chen, G., Liu, S., Bandy, A., Thornton, D., Guan, H., and Sandholm, S.: Impact of ship emissions on marine boundary layer $\mathrm{NO}_{x}$ and $\mathrm{SO}_{2}$ Distributions over the Pacific Basin, Geophys. Res. Lett., 28, 235-238, doi:10.1029/2000g1012013, 2001.

Esler, J. G., Roelofs, G. J., Köhler, M. O., and O’Connor, F. M.: A quantitative analysis of grid-related systematic errors in oxidising capacity and ozone production rates in chemistry transport models, Atmos. Chem. Phys., 4, 1781-1795, doi:10.5194/acp-41781-2004, 2004.

Fiore, A. M., Jacob, D. J., Mathur, R., and Martin, R. V.: Application of empirical orthogonal functions to evaluate ozone simulations with regional and global models, J. Geophys. Res., 108, 4431, doi:10.1029/2002jd003151, 2003.

Fisher, J. A., Jacob, D. J., Travis, K. R., Kim, P. S., Marais, E. A., Chan Miller, C., Yu, K., Zhu, L., Yantosca, R. M., Sulprizio, M. P., Mao, J., Wennberg, P. O., Crounse, J. D., Teng, A. P., Nguyen, T. B., St. Clair, J. M., Cohen, R. C., Romer, P., Nault, B. A., Wooldridge, P. J., Jimenez, J. L., Campuzano-Jost, P., Day, D. A., Shepson, P. B., Xiong, F., Blake, D. R., Goldstein, A. H., Misztal, P. K., Hanisco, T. F., Wolfe, G. M., Ryerson, T. B., Wisthaler, A., and Mikoviny, T.: Organic nitrate chemistry and its implications for nitrogen budgets in an isoprene- and monoterpene-rich atmosphere: constraints from aircraft $\left(\mathrm{SEAC}^{4} \mathrm{RS}\right)$ and ground-based (SOAS) observations in the Southeast US, Atmos. Chem. Phys. Discuss., doi:10.5194/acp-2016-52, in review, 2016.

Gillani, N. and Pleim, J.: Sub-grid scale features of anthropogenic emissions of $\mathrm{NO}_{x}$ and VOC in the context of regional Eulerian models, Atmos. Environ., 30, 2043-2059, doi:10.1016/13522310(95)00201-4, 1996.

Guenther, A. B., Jiang, X., Heald, C. L., Sakulyanontvittaya, T., Duhl, T., Emmons, L. K., and Wang, X.: The Model of Emissions of Gases and Aerosols from Nature version 2.1 (MEGAN2.1): an extended and updated framework for modeling biogenic emissions, Geosci. Model Dev., 5, 1471-1492, doi:10.5194/gmd-51471-2012, 2012.

Hair, J. W., Hostetler, C. A., Cook, A. L., Harper, D. B., Ferrare, R. A., Mack, T. L., Welch, W., Izquierdo, L. R., and Hovis, F. E.: Airborne High Spectral Resolution Lidar for profiling aerosol optical properties, Appl. Optics, 47, 6734-6752, doi:10.1364/AO.47.006734, 2008.

Hansel, A., Jordan, A., Warneke, C., Holzinger, R., Wisthaler, A., and Lindinger, W.: Proton-transfer-reaction mass spectrometry (PTR-MS): on-line monitoring of volatile organic compounds at volume mixing ratios of a few pptv, Plasma Sources Sci. T., 8, 332, doi:10.1088/0963-0252/8/2/314, 1999.

Henderson, B. H., Jeffries, H. E., Kim, B.-U., and Vizuete, W. G.: The influence of model resolution on ozone in industrial volatile organic compound plumes, J. Air Waste Manage., 60, 11051117, doi:10.3155/1047-3289.60.9.1105, 2010.

Hudman, R. C., Moore, N. E., Mebust, A. K., Martin, R. V., Russell, A. R., Valin, L. C., and Cohen, R. C.: Steps towards a mechanistic model of global soil nitric oxide emissions: implementation and space based-constraints, Atmos. Chem. Phys., 12, 7779-7795, doi:10.5194/acp-12-7779-2012, 2012.

Ito, A., Sillman, S., and Penner, J. E.: Global chemical transport model study of ozone response to changes in chemical kinet- 
ics and biogenic volatile organic compounds emissions due to increasing temperatures: Sensitivities to isoprene nitrate chemistry and grid resolution, J. Geophys. Res.-Atmos., 114, D09301, doi:10.1029/2008jd011254, 2009.

Jacob, D. J. and Wofsy, S. C.: Budgets of reactive nitrogen, hydrocarbons, and ozone over the Amazon forest during the wet season, J. Geophys. Res.-Atmos., 95, 16737-16754, doi:10.1029/JD095iD10p16737, 1990.

Jang, J.-C., Jeffries, H., Byun, D., and Pleim, J.: Sensitivity of zzone to model grid resolution - I. Application of high resolution regional acid deposition model, Atmos. Environ., 29, 3085-3100, doi:10.1016/1352-2310(95)00118-I, 1995.

Kiley, C. M., Fuelberg, H. E., Palmer, P. I., Allen, D. J., Carmichael, G. R., Jacob, D. J., Mari, C., Pierce, B., Pickering, K. E., Tang, Y., Wild, O., Fairlie, T. D., Logan, J. A., Sachse, G. W., Shaack, T. K., and Streets, D. G.: An intercomparison and evaluation of aircraft-derived and simulated $\mathrm{CO}$ from seven chemical transport models during the TRACE-P experiment, J. Geophys. Res., 108, 8819, doi:10.1029/2002jd003089, 2003.

Kim, P. S., Jacob, D. J., Fisher, J. A., Travis, K., Yu, K., Zhu, L., Yantosca, R. M., Sulprizio, M. P., Jimenez, J. L., CampuzanoJost, P., Froyd, K. D., Liao, J., Hair, J. W., Fenn, M. A., Butler, C. F., Wagner, N. L., Gordon, T. D., Welti, A., Wennberg, P. O., Crounse, J. D., St. Clair, J. M., Teng, A. P., Millet, D. B., Schwarz, J. P., Markovic, M. Z., and Perring, A. E.: Sources, seasonality, and trends of southeast US aerosol: an integrated analysis of surface, aircraft, and satellite observations with the GEOS-Chem chemical transport model, Atmos. Chem. Phys., 15, 10411-10433, doi:10.5194/acp-15-10411-2015, 2015.

Kumar, N. and Russell, A. G.: Multiscale air quality modeling of the northeastern United States, Atmos. Environ., 30, 1099-1116, doi:10.1016/1352-2310(95)00317-7, 1996.

Liang, J. and Jacobson, M. Z.: Effects of subgrid segregation on ozone production efficiency in a chemical model, Atmos. Environ., 34, 2975-2982, doi:10.1016/S1352-2310(99)00520-8, 2000

Liu, S. C., Trainer, M., Fehsenfeld, F. C., Parrish, D. D., Williams, E. J., Fahey, D. W., Hübler, G., and Murphy, P. C.: Ozone production in the rural troposphere and the implications for regional and global ozone distributions, J. Geophys. Res.-Atmos., 92, 41914207, doi:10.1029/JD092iD04p04191, 1987.

Mao, J., Paulot, F., Jacob, D. J., Cohen, R. C., Crounse, J. D., Wennberg, P. O., Keller, C. A., Hudman, R. C., Barkley, M. P., and Horowitz, L. W.: Ozone and organic nitrates over the eastern United States: Sensitivity to isoprene chemistry, J. Geophys. Res.-Atmos., 118, 11256-11268, doi:10.1002/jgrd.50817, 2013.

Marais, E. A., Jacob, D. J., Kurosu, T. P., Chance, K., Murphy, J. G., Reeves, C., Mills, G., Casadio, S., Millet, D. B., Barkley, M. P., Paulot, F., and Mao, J.: Isoprene emissions in Africa inferred from OMI observations of formaldehyde columns, Atmos. Chem. Phys., 12, 6219-6235, doi:10.5194/acp-12-62192012, 2012.

Marais, E. A., Jacob, D. J., Jimenez, J. L., Campuzano-Jost, P., Day, D. A., Hu, W., Krechmer, J., Zhu, L., Kim, P. S., Miller, C. C., Fisher, J. A., Travis, K., Yu, K., Hanisco, T. F., Wolfe, G. M., Arkinson, H. L., Pye, H. O. T., Froyd, K. D., Liao, J., and McNeill, V. F.: Aqueous-phase mechanism for secondary organic aerosol formation from isoprene: application to the southeast United States and co-benefit of $\mathrm{SO}_{2}$ emission controls, At- mos. Chem. Phys., 16, 1603-1618, doi:10.5194/acp-16-16032016, 2016.

Mathur, R., Shankar, U., Hanna, A. F., Odman, M. T., McHenry, J. N., Coats, C. J., Alapaty, K., Xiu, A., Arunachalam, S., Olerud, D. T., Byun, D. W., Schere, K. L., Binkowski, F. S., Ching, J. K. S., Dennis, R. L., Pierce, T. E., Pleim, J. E., Roselle, S. J., and Young, J. O.: Multiscale Air Quality Simulation Platform (MAQSIP): Initial applications and performance for tropospheric ozone and particulate matter, J. Geophys. Res.-Atmos., 110, D13308, doi:10.1029/2004jd004918, 2005.

Murray, L. T., Jacob, D. J., Logan, J. A., Hudman, R. C., and Koshak, W. J.: Optimized regional and interannual variability of lightning in a global chemical transport model constrained by LIS/OTD satellite data, J. Geophys. Res.-Atmos., 117, D20307, doi:10.1029/2012jd017934, 2012.

National Research Council: A National Strategy for Advancing Climate Modeling, Report, National Research Council Board on Atmospheric Science and Climate, Washington, D.C., 2012.

Palmer, P. I., Jacob, D. J., Fiore, A. M., Martin, R. V., Chance, K., and Kurosu, T. P.: Mapping isoprene emissions over North America using formaldehyde column observations from space, J. Geophys. Res.-Atmos., 108, 4180, doi:10.1029/2002jd002153, 2003.

Parrella, J. P., Jacob, D. J., Liang, Q., Zhang, Y., Mickley, L. J., Miller, B., Evans, M. J., Yang, X., Pyle, J. A., Theys, N., and Van Roozendael, M.: Tropospheric bromine chemistry: implications for present and pre-industrial ozone and mercury, Atmos. Chem. Phys., 12, 6723-6740, doi:10.5194/acp-12-6723-2012, 2012.

Richter, D., Weibring, P., Walega, J., Fried, A., Spuler, S., and Taubman, M.: Compact highly sensitive multi-species airborne mid-IR spectrometer, Appl. Phys. B, 119, 119-131, doi:10.1007/s00340-015-6038-8, 2015.

Ryerson, T. B., Williams, E. J., and Fehsenfeld, F. C.: An efficient photolysis system for fast-response $\mathrm{NO}_{2}$ measurements, J. Geophys. Res.-Atmos., 105, 26447-26461, doi:10.1029/2000JD900389, 2000.

SEAC4RS Science Team: Studies of Emissions and Atmospheric Composition, Clouds and Climate Coupling by Regional Surveys (SEAC4RS), doi:10.5067/Aircraft/SEAC4RS/AerosolTraceGas-Cloud, 2016.

Shrestha, K. L., Kondo, A., Kaga, A., and Inoue, Y.: Highresolution modeling and evaluation of ozone air quality of Osaka using MM5-CMAQ system, J. Environ. Sci., 21, 782-789, doi:10.1016/s1001-0742(08)62341-4, 2009.

Sillman, S., Logan, J. A., and Wofsy, S. C.: A regional scale model for ozone in the United States with subgrid representation of urban and power plant plumes, J. Geophys. Res., 95, 5731-5748, doi:10.1029/JD095iD05p05731, 1990.

Taylor, K. E.: Summarizing multiple aspects of model performance in a single diagram, J. Geophys. Res., 106, 7183, doi:10.1029/2000jd900719, 2001.

Tie, X., Brasseur, G., and Ying, Z.: Impact of model resolution on chemical ozone formation in Mexico City: application of the WRF-Chem model, Atmos. Chem. Phys., 10, 8983-8995, doi:10.5194/acp-10-8983-2010, 2010.

Toon, O. B., Maring, H., Dibb, J., Ferrare, R., Jacob, D. J., Jensen, E. J., Luo, Z. J., Mace, G. G., Pan, L. L., Pfister, L., Rosenlof, K. H., Redemann, J., Reid, J. S., Singh, H. B., Yokelson, R., Chen, G., Jucks, K. W., and Pszenny, A.: Planning, implementation, and scientific goals of the Studies of Emissions and Atmo- 
spheric Composition, Clouds, and Climate Coupling by Regional Surveys (SEAC ${ }^{4} \mathrm{RS}$ ) field mission, J. Geophys. Res.-Atmos., in review, 2016.

Travis, K. R., Jacob, D. J., Fisher, J. A., Kim, P. S., Marais, E. A., Zhu, L., Yu, K., Miller, C. C., Yantosca, R. M., Sulprizio, M. P., Thompson, A. M., Wennberg, P. O., Crounse, J. D., St. Clair, J. M., Cohen, R. C., Laugher, J. L., Dibb, J. E., Hall, S. R., Ullmann, K., Wolfe, G. M., Pollack, I. B., Peischl, J., Neuman, J. A., and Zhou, X.: $\mathrm{NO}_{x}$ emissions, isoprene oxidation pathways, vertical mixing, and implications for surface ozone in the Southeast United States, Atmos. Chem. Phys. Discuss., doi:10.5194/acp2016-110, in review, 2016.

Valari, M. and Menut, L.: Does an increase in air quality models' resolution bring surface ozone concentrations closer to reality?, J. Atmos. Ocean Tech., 25, 1955-1968, doi:10.1175/2008jtecha1123.1, 2008.

Valin, L. C., Russell, A. R., Hudman, R. C., and Cohen, R. C.: Effects of model resolution on the interpretation of satellite $\mathrm{NO}_{2}$ observations, Atmos. Chem. Phys., 11, 11647-11655, doi:10.5194/acp-11-11647-2011, 2011.

Vinken, G. C. M., Boersma, K. F., Jacob, D. J., and Meijer, E. W.: Accounting for non-linear chemistry of ship plumes in the GEOS-Chem global chemistry transport model, Atmos. Chem. Phys., 11, 11707-11722, doi:10.5194/acp-11-11707-2011, 2011. Wild, O. and Prather, M. J.: Global tropospheric ozone modeling: Quantifying errors due to grid resolution, J. Geophys. Res., 111, D11305, doi:10.1029/2005jd006605, 2006.
Yamaji, K., Ikeda, K., Irie, H., Kurokawa, J., and Ohara, T.: Influence of model grid resolution on $\mathrm{NO}_{2}$ vertical column densities over East Asia, J. Air Waste Manage., 64, 436-444, doi:10.1080/10962247.2013.827603, 2014.

Zhang, L., Jacob, D. J., Downey, N. V., Wood, D. A., Blewitt, D., Carouge, C. C., van Donkelaar, A., Jones, D. B. A., Murray, L. T., and Wang, Y.: Improved estimate of the policyrelevant background ozone in the United States using the GEOS-Chem global model with $1 / 2^{\circ} \times 2 / 3^{\circ}$ horizontal resolution over North America, Atmos. Environ., 45, 6769-6776, doi:10.1016/j.atmosenv.2011.07.054, 2011.

Zhu, L., Jacob, D. J., Kim, P. S., Fisher, J. A., Yu, K., Travis, K. R., Mickley, L. J., Yantosca, R. M., Sulprizio, M. P., De Smedt, I., Gonzalez Abad, G., Chance, K., Li, C., Ferrare, R., Fried, A., Hair, J. W., Hanisco, T. F., Richter, D., Scarino, A. J., Walega, J., Weibring, P., and Wolfe, G. M.: Observing atmospheric formaldehyde ( $\mathrm{HCHO}$ ) from space: validation and intercomparison of six retrievals from four satellites (OMI, GOME2A, GOME2B, OMPS) with SEAC ${ }^{4} \mathrm{RS}$ aircraft observations over the Southeast US, Atmos. Chem. Phys. Discuss., doi:10.5194/acp-2016-162, in review, 2016. 